\title{
The Effect of Lavender and Rose Aromatherapy on the Intensity of Active Phase Childbirth Pain in the Manyak Payed Community Health Center, Aceh Tamiang Regency, Indonesia
}

\author{
Salmiani Abdul Manaf*, Cut Yuniwati, Silfia Dewi, Lili Kartika Harahap \\ Department of Midwifery, Polytechnic of Health-Ministry of Health, Aceh, Indonesia
}

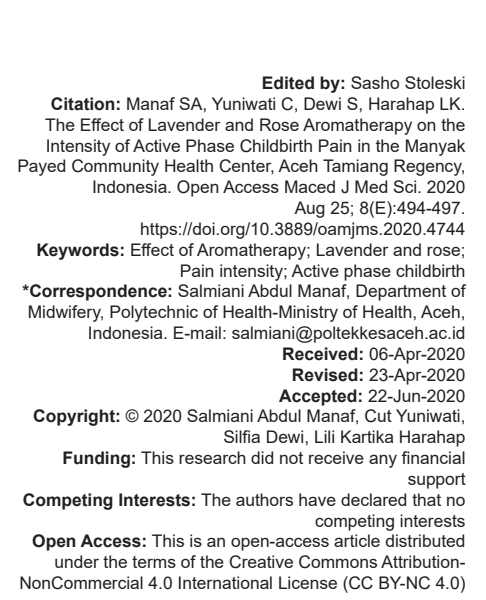

\section{Introduction}

According to the WHO data, as many as $99 \%$ of maternal deaths are due to childbirth or birth problems [1]. High mortality rates are generally caused by a lack of knowledge about the causes and management of complications of pregnancy, childbirth, and the postpartum. Childbirth is a physiological process that occurs in every woman. Childbirth is a process of spending the results of the conception out of the womb through the birth canal. Most postpartum mothers feel pain. Physiologically labor pain occurs when the uterine muscle contracts in an effort to open the cervix and push the baby's head toward the pelvis. Labor pain starts in the first stage of the latent phase, which is the process of opening the cervix from $4 \mathrm{~cm}$ to $10 \mathrm{~cm}$. In the active phase toward the opening peak, there is an increase in the intensity and frequency of contractions, so the peak pain response is in this phase [2]. Childbirth pain that arises more often and longer can cause the mother to be restless, afraid, and tense and even stressed which results in excessive release of hormones such as adrenaline, catecholamines, and steroids. The most dominant pain with a long time is felt that the pain in the first stage [3]. Childbirth pain in the active phase will be felt more severe, sharp, and cramping and cause pain sensations [4]. Increased catecholamines can cause disturbances in the strength of uterine contractions, causing uterine inertia that affects the prolonged parturition and increases maternal and infant mortality rates [5]. Efforts to increase comfort and reduce pain in maternal can be done using non-pharmacological methods. Aromatherapy is currently one of the nonpharmacological methods in reducing labor pain. The use of aromatherapy seems increasingly flourished as a healing practice. Some studies show that aromatherapy lavender essence can be an effective therapeutic choice for pain management for women in labor [6], [7]. Based on this background, the study aimed at comparison of the effect of lavender aromatherapy and rose flower tea on the intensity of labor pain in the first phase of active phase in the work area of the Manyak Payed Community Health Center, Aceh Tamiang Regency, Indonesia. 


\section{Methods}

The quasi-experimental design was used in this study with a post-test. The sample in this study was divided into three grub, and Only the control group in three groups that were given different interventions. This research has been successfully carried out in the working area of Manyak Payed Community Health Center from June to December 2019. All mothers giving birth in June to December have been selected as a population with a sample of 54 women giving birth using accidental sampling techniques. This sample of 54 people was divided into three groups. Each group numbered 18 people. The sample in this study used inclusions and exclusion criteria. data analysis uses univariable and bivariable. Testing data using the Kruskal-Wallis $\mathrm{H}$ test and the Mann-Whitney test.

\section{Results}

\section{Univariate analysis}

Univariate analysis was conducted to find out the frequency distribution of respondents' characteristics in the form of the mother's age, mother's education, and mother's occupation. The results can be seen in Table 1:

Table 1: Characteristics of respondents by age, occupation, and education in maternity mothers

\begin{tabular}{lll}
\hline Characteristics & $\mathrm{f}$ & $\%$ \\
\hline Age & 5 & \\
$\quad<20$ & 49 & 9.3 \\
$20-35$ & & 90.7 \\
Occupation & 25 & 46.3 \\
$\quad$ Employed & 29 & 53.7 \\
$\quad$ Unemployed & & \\
Education & 36 & 66.7 \\
$\quad$ High school & 18 & 33.3 \\
$\quad$ University & & \\
\hline
\end{tabular}

The majority of respondents aged $20-35$ years were 49 respondents $(90.7 \%)$. Based on employment status, the majority of working mothers were 29 respondents $(53.7 \%)$. Based on the status of education, the majority of mothers with a high school education were 36 respondents $(66.7 \%)$.

\section{Bivariate analysis}

After characterizing each variable, the analysis was continued at the bivariate level. The first test was conducted to determine differences in the intensity of labor pain.

\section{Normality test}

A normality test is done to see whether the data are normal or not. The test used in the normality test is the Shapiro-Wilk test. Normality test requirements if normal data use parametric tests and if data is not normal to use non-parametric tests. The results can be seen in Table 2.

Table 2: Normality test in the control group, lavender aromatherapy, and rose

\begin{tabular}{llll}
\hline Groups & Statistics & Sig. & Info \\
\hline Control & 0.849 & 0.032 & Normal \\
Lavender aromatherapy & 0.872 & 0.030 & Normal \\
Rose aromatherapy & 0.912 & 0.010 & Normal \\
\hline
\end{tabular}

The above table is known that the three groups have abnormal distribution with Sig. the control group 0.032 , the 0.030 lavender group, and the 0.010 rose flower group $(<0.05)$. It can be interpreted that the data are not normally distributed and further testing uses the parametric test, the Kruskal-Wallis $\mathrm{H}$. test.

\section{Homogeneity test}

Homogeneity test is carried out to find out if the data variant is the same (homogeneous) or not the same, using the Levene statistical test.

Table 3 is known that the variant data are homogeneous with a statistical Levene value of 0.187 and Sig. 0.830 (>0.05). Subsequent testing of the post hoc test used the Mann-Whitney test.

Table 3: Homogeneity test in the control group, lavender aromatherapy, and rose flower

\begin{tabular}{llll}
\hline Variable & Levene statistics & Sig. & Note \\
\hline Childbirth pain & 0.187 & 0,830 & Homogen \\
\hline
\end{tabular}

\section{Kruskal-Wallis test $H$}

The Kruskal-Wallis $\mathrm{H}$ test was carried out to determine the average difference for each group. The test results can be seen in Table 4:

Table 4: Distribution of difference in mean intensity of first stage of childbirth

\begin{tabular}{llll}
\hline Childbirth pain & Mean RANK & Std. deviation & p-value \\
\hline Control & 37.06 & 1.115 & 0.001 \\
Lavender & 18.83 & & \\
Rose & 26.61 & & \\
\hline
\end{tabular}

The table shows the difference in mean rank in the three groups, namely, the control group 37.06, the lavender group 18.83, and the rose flower group 26.61. Of the three groups, labor pain in the lavender group was the lowest. Willis $\mathrm{H}$ crucial test results are known that there are differences in ineffectiveness in the control group and the treatment group with the Sig. 0.001 (<0.05). These results can be concluded that $\mathrm{Ha}$ was accepted and Ho was rejected. Furthermore, to find out which group is the most effective in reducing the first stage of labor pain using the post hoc test.

\section{Post hoc test}

Post hoc tests are performed to find out which groups (variables) are the most effective in reducing labor pain. In the homogeneity test, the results of homogeneous data (the same data variant), the test 
used is the Mann-Whitney test. The results can be seen in Table 5.

Table 5: Mann-Whitney test table differences in the effectiveness of lavender and rose aromatherapy on pain in the first stage of active phase

\begin{tabular}{lll}
\hline Group & Mean rank & Sig. \\
\hline Lavender & 12.67 & 0.001 \\
Control & 24.43 & \\
Lavender & 14.78 & 0.027 \\
Control & 22.22 & \\
Rose & 15.67 & 0.90 \\
Lavender & 21.33 & \\
\hline
\end{tabular}

The table is known that there are differences

in the intensity of childbirth pain between the control group and the lavender aromatherapy group, aimed at sig. values $0.001(<0.05)$. The same results were aimed at the control group and rose flower aromatherapy data with sig. values $0.027(<0.05)$ which means that there is no significant difference in the decrease in labor pain intensity between the two groups. Different results were obtained in the lavender and rose flower aromatherapy groups where the results obtained were not different between the two groups with sig. values $0.90(p>0.05)$. Both treatment groups were equally effective in reducing the intensity of labor in the first phase of active labor.

\section{Discussion}

Childbirth pain can be overcome by using various methods, namely, pharmacological methods and non-pharmacological methods. Nonpharmacological can be done by giving aromatherapy. Aromatherapy is currently one of the nonpharmacological methods in reducing childbirth pain. The use of aromatherapy seems increasingly flourished as a healing practice. The results of this study note that there is an effect of lavender aromatherapy on the intensity of labor in the first phase of active labor. Furthermore, the results of this study also found that there were differences in the mean intention of pain in each group. In the control group, the mean labor pain was 37.06 . In the lavender group, the pain was 18.81. In the rose flower group, the average pain was 26.61. Willis $\mathrm{H}$ crucial test results are known that there are differences in ineffectiveness in the control group and the treatment group with the Sig. $0.001(<0.05)$. Aromatherapy rose flower can reduce the intensity of labor pain in maternity because the aroma of rose flowers can create a sense of comfort and reduce pain. Aromatherapy lavender essence can be an effective therapeutic choice for pain management for women in childbirth [7]. Women with lower anxiety levels will experience less pain during labor [8]. The pain in labor is caused by a combination of stretching the lower uterine segment (hereafter the cervix) and ischemia (hypoxia) of the uterine muscles. The reaction to pain is a very individual response. This reaction depends on the personality, emotional condition and level of understanding of the patient, cultural background, family and education, and previous experience. The use of aromatherapy roses can foster a feeling of calm in the body, mind, and spirit. One safe and effective addition to the prevention and treatment of emotional distress is aromatherapy [9]. Aromatherapy roses also have local analgesic and antispasmodic effects [10]. The aroma of rose that is inhaled with deep breathing will increase the entry of the number of aromatic substances into the body which stimulates the work of brain neurochemical cells. Excessive pain often causes the mother to feel uncomfortable. Post episiotomy discomfort and its consequences can affect the quality of life of the mother and the mental health and relationship of the mother and babies [11]. The use of aromatherapy can reduce anxiety. Lavender aromatherapy has a beneficial effect on anxiety in patients undergoing surgery [12]. Aromatherapy can also be used for the treatment of post-operative pain and for patients who have chronic diseases [13]. Aromatherapy for cancer patients includes decreased levels of anxiety and reduction in emotional stress, pain, muscle tension, and fatigue [14]. Aromatherapy massage with lavender essential oil can reduce pain in patients with knee osteoarthritis [15]. Aromatherapy is effective in improving sleep quality and massage methods are more effective in improving sleep quality [16]. Aromatherapy can continue to be used as a complementary and alternative therapy for patients with depression and secondary depression symptoms that arise from various types of chronic medical conditions [17], [18]. Aromatherapy lavender fleur oil will reduce anxiety when given to women before undergoing surgery [17], [19]. There is a difference in the effect of lavender and rose flower aromatherapy because the two intervention groups are equally influential on the intensity of labor pain in the active phase of the first phase of labor. Aromatherapy lavender and rose flower therapy are useful for relaxation, anxiety, and mood and post-surgery shows decreased anxiety, improved mood, and increased relaxation.

\section{Conclusion}

The average labor pain in the lavender group was 18.83, the rose flower group was 26.21, and the control group was 37.06. Of the three groups, the labor pain in the lavender group was the lowest. Willis $H$ crucial test results are known that there are differences in ineffectiveness in the control group and the treatment group with the sig. $0.001(<0.05)$. In further tests of the post hoc test using the Mann-Whitney test, it was found that there was no difference in the effectiveness of the intensity of labor pain in the active phase I with a sig. $0.90(p>0.05)$. 


\section{References}

1. World Health Organization. Trends in Maternal Mortality: 1999 to 2008. Geneva: World Health Organization Press; 2010.

2. Martin R, Koniak G. In: Afiyati AB, editor. Keperawatan Maternitas: Kesehatan Wanita, Bayi dan Keluarga. $18^{\text {th }}$ ed. Jakarta: EGC; 2012.

3. Manuaba. IImu Kebidanan, Kandungan dan KB. Jakarta: EGC; 2008.

4. Afifah D, Budi M, Ninik P. Different levels of labor pain when i in primigravida and multi gravida normal maternity mothers. J Univ Muhammadiyah Semarang. 2011;1:2-7.

5. Bare G, Smeltzer C. Buku Ajar Keperawatan Medikal Bedah Brunner and Suddarth. Jakarta: EGC; 2002.

6. Bakhtshirin F, Abedi S, YusefiZoj P, Razmjooee D. The effect of aromatherapy massage with lavender oil on severity of primary dysmenorrhea in Arsanjan students. Iran J Nurs Midwifery Res. 2015;20(1):156-60.

PMid:25709705.

7. Yazdkhasti M, Pirak A. The effect of aromatherapy with lavender essence on severity of labor pain and duration of labor in primiparous women. Complement Ther Clin Pract. 2016;25:816. https://doi:10.1016/j.ctcp.2016.08.008 PMid:27863615

8. Ghiasi A, Bagheri L, Haseli A. A Systematic review on the anxiolytic effect of aromatherapy during the first stage of labor. J Caring Sci. 2019;8(1):51-60. https://doi:10.15171/jcs.2019.008 PMid:30915314

9. Butje A, Repede E, Shattell MM. Healing scents: An overview of clinical aromatherapy for emotional distress. J Psychosoc Nurs Ment Health Serv. 2008;46(10):46-52. https:// doi:10.3928/02793695-20081001-12 PMid:18935936

10. Hamdamian S, Nazarpour S, Simbar M, Hajian S, Mojab F, Talebi A. Effects of aromatherapy with Rosa damascena on nulliparous women's pain and anxiety of labor during first stage of labor. J Integr Med. 2018;16(2):120-5. https://doi:10.1016/j. joim.2018.02.005 PMid:29526235

11. Sheikhan F, Jahdi F, Khoei EM, Shamsalizadeh N, Sheikhan M, Haghani $\mathrm{H}$. Episiotomy pain relief: Use of lavender oil essence in primiparous Iranian women. Complement Ther Clin Pract. 2012;18(1):66-70. https://doi:10.1016/j.ctcp.2011.02.003

\section{PMid:22196577}

12. Karaman T, Karaman S, Dogru S, Tapar H, Sahin A, Suren M, et al. Evaluating the efficacy of lavender aromatherapy on peripheral venous cannulation pain and anxiety: A prospective, randomized study. Complement Ther Clin Pract. 2016;23:64-8. https://doi:10.1016/j.ctcp.2016.03.008

\section{PMid:27157961}

13. Antonelli M, Donelli D. Efficacy, Safety and tolerability of aroma massage with lavender essential oil: An overview. Int J Ther Massage Bodywork. 2020;13(1):32-6

PMid:32133043

14. Boehm K, Büssing A, Ostermann T. Aromatherapy as an adjuvant treatment in cancer care--a descriptive systematic review. Afr J Tradit Complement Altern Med. 2012;9(4):503-18. eCollection 2012. https://doi:10.4314/ajtcam.v9i4.7 PMid:23983386

15. Nasiri A, Mahmodi MA. Aromatherapy massage with lavender essential oil and the prevention of disability in ADL in patients with osteoarthritis of the knee: A randomized controlled clinical trial. Complement Ther Clin Pract. 2018;30:116-21. https:// doi:10.1016/j.ctcp.2017.12.012

PMid:29389470

16. Kim ME, Jun JH, Hur MH. Effects of aromatherapy on sleep quality: A systematic review and meta-analysis. J Korean Acad Nurs. 2019;49(6):655-76. https://doi:10.4040/ jkan.2019.49.6.655

PMid:31932562

17. Yim VW, Ng AK, Tsang HW, Leung AY. A review on the effects of aromatherapy for patients with depressive symptoms. J Altern Complement Med. 2009;15(2):187-95. https://doi:10.1089/ acm.2008.0333

PMid:19216657

18. Hassanzadeh M, Kiani F, Bouya S, Zarei M. Comparing the effects of relaxation technique and inhalation aromatherapy on fatigue in patients undergoing hemodialysis. Complement Ther Clin Pract. 2018;31:210-4. https://doi:10.1016/j. ctcp.2018.02.019 PMid:29705457

19. Franco L, Banck TJ, Dugan K, Kline R, Shanmugam G, Galotti A et al. Both lavender fleur oil and unscented oil aromatherapy reduce preoperative anxiety in breast surgery patients: A randomized trial. J Clin Anesth. 2016;33:243-9. https:// doi:10.1016/j.jclinane.2016.02.032

PMid:27555173 